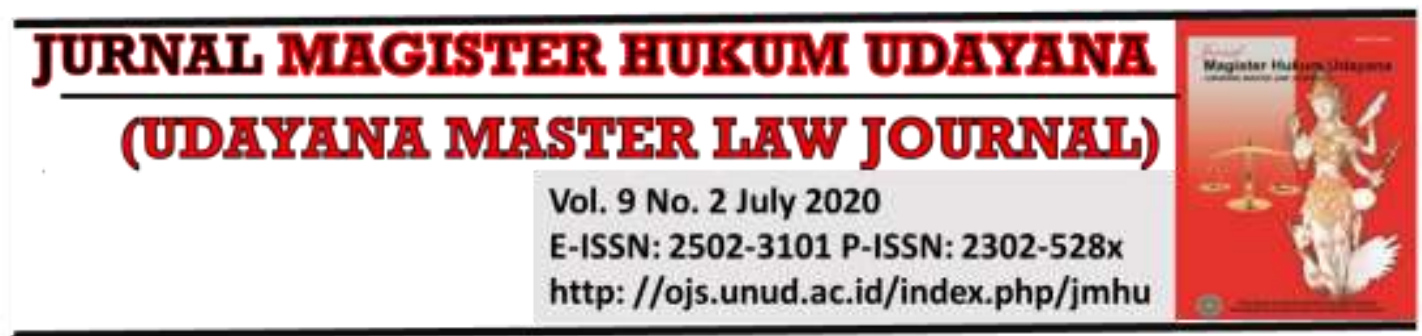

\title{
Jagaddhita Family Saves Children from Violence and Exploitation: A Perspective on the Usage of the Non-Penal Policy
}

\author{
AAA Ngurah Tini Rusmini Gorda', I Gede Agus Kurniawan² \\ ${ }^{1}$ Faculty of Law and Social Sciences, Universitas Pendidikan Nasional, E-mail: \\ tinirusmini@undiknas.ac.id \\ ${ }^{2}$ Faculty of Law and Social Sciences, Universitas Pendidikan Nasional, E-mail: \\ gedeaguskurniawan@undiknas.ac.id
}

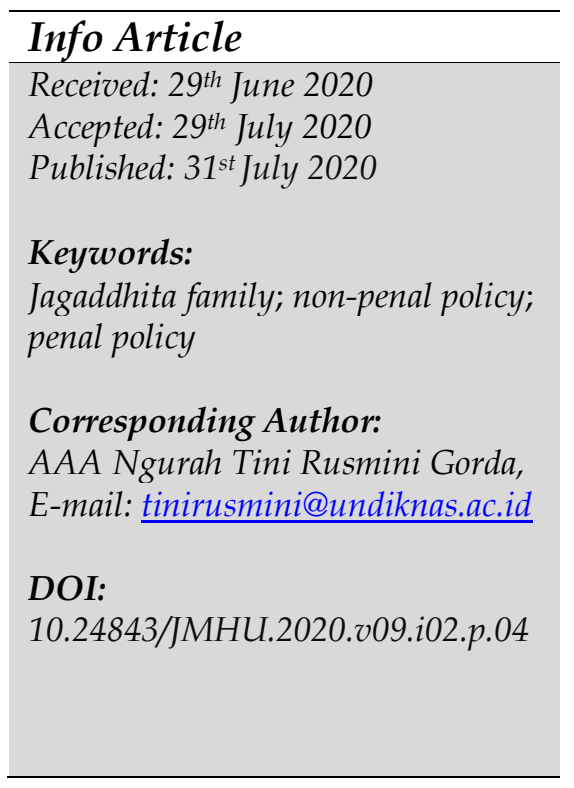

\begin{abstract}
The purpose of this article is to examine the child protection that is integral/simultaneous and prioritizing the non-penal policy by forming and realizing the Jagaddhita family. This research is normative juridical research. The results show that in terms of penal-policy the State has provided a legal umbrella through the Law of the Republic of Indonesia No. 23 of 2002 on Child Protection as amended by the Law of the Republic of Indonesia No. 35 of 2014. However, as time goes by such Law is deemed unable to run effectively and the crime against children is increased. Establishing the Jagaddhita family as a non-penal policy is a strategic effort in eliminating any crime related to children. Such establishment is the goal of a marriage in which the marriage itself has four (4) main objectives namely Dharma, Artha, Kama, and Praja that will lead to the birth of good children.
\end{abstract}

\section{Introduction}

Nowadays, life has changes and develops rapidly. The development of technology and information makes national boundaries as if they no longer exist. In this digitalization era, access to internet services plays an important role in various activities such as eGovernment, e-Learning, e-Banking, e-Business and several other activities. ${ }^{1}$ Especially during this New Normal Era, the society is trying to adapt new activities, for example, the way we change behavior, lifestyles, and habits in the new life order that includes changes in the way of law.

Western cultures dominate the developing countries' culture, including Indonesia. The wider community of Indonesia is responsible for warding off foreign cultures that are incompatible with Indonesian culture that lead to negative impact. Quality of

\footnotetext{
1 Supasti Dharmawan, N. K., Dewi Kasih, D. P., \& Stiawan, D. (2019). Personal Data Protection And Liability Of Internet Service Provider: A Comparative Approach.International Journal of Electrical \& Computer Engineering, 9(4), pp. 3175 3184, DOI: 10.11591/ijece.v9i4.pp3175-3184
} 
education plays an important role in creating Indonesian society that is intelligent, creative, healthy, independent, faithful, and founded on the belief in God Almighty. ${ }^{2}$

Related to the above situation, the family is the foothold and the forefront that is expected to create a qualified young generation by providing an appropriate pattern of children's character building. Violence is often found in society as a phenomenon in the family to discipline the children. Data from the Indonesian Child Protection Commission (KPAI) in 2014 shows that there were 93 cases of violence against children, in which $13 \%$ of the perpetrators were family members. ${ }^{3}$ On other data, the KPAI reveals that it had seen the results of a screening conducted by the Indonesian Ministry of Health for elementary school children at the end of 2017 that was published in March 2018. It is noted that there was a surprising fact that from the 6.000 samples taken, $91.58 \%$ have been exposed to pornography, around $6.3 \%$ experienced mild pornography addiction, and around $0.07 \%$ had severe addiction. Five (5) other surveys also found shocking data where $97 \%$ of respondents were junior high school and senior high school students in 12 major cities in Indonesia have admitted that they have accessed sites that offer pornographic content and watch porn videos through the internet. ${ }^{4}$

Gorda argues that a happy and peaceful family (grha jagaddhita) is the most important part of children's life. ${ }^{5}$ The main goal of having a child is a Jagaddhita family where dignity and rights as human beings that must be upheld are attached to it. ${ }^{6}$ Children's human rights are part of universal human rights that are contained in children's rights. 7

A child is an inseparable part of a human, nation, and state survival. In order to be able to take responsibility for the nation and state survival, every child needs to receive the broadest possible protection and opportunity to grow and develop optimally both physically, mentally, and socially. Therefore, protection is necessary to realize the children's welfare by providing a guarantee for the fulfillment of their rights without discriminatory treatment. ${ }^{8}$ Such protection should be done in order to avoid various

\footnotetext{
2 Budiadnya, P. (2019). Peran Guru Rupaka Daalam Menanamkan Ajaran Agama Hindu Dalam Keluarga Di Kota Surakarta. Kamaya: Jurnal Ilmu Agama, 2(2), 123-142. Please also see the Law of the Republic of Indonesia No. 20 of 2003 on National Educational System.

${ }^{3}$ Nurwita, A., Nurfitriani, E., \& Yuniarti, S. (2017). Hubungan Status Ekonomi Dan Pandangan Posisi Anak Dengan Sikap Orang Tua Terhadap Kekerasan Pada Anak. Jurnal Kesehatan, 8(1), 955-960.

${ }^{4}$ Sofian, A., Pratama, B., \& Talerico, C. (2018). Weighting Approaches on Online Sexual Abuse of Children: Cultural Prevention or Crime-Based Enforcement?. Udayana Journal Of Law And Culture, 2(2), 191-219. doi:10.24843/UJLC.2018.v02.i02.p04

${ }^{5}$ Gorda, I G. N. 2006. Mendidik Suputra Dalam Kandungan Ibu, Denpasar. Astra Brata Bali, p. 11

${ }^{6}$ See the Law of the Republic of Indonesia No. 35 of 2014 on the Amendment of the Law of the Republic of Indonesia No. 23 of 2002 on Child Protection

7 Fitroh, M. 2014. Perlindungan Hak Asasi Manusia Anak di Indonesia. Available from http://www.kompasiana.com/fitrohmufidatul/perlindungan-hak-asasi-manusia-anak-diindonesia, accessed on 1 June 2020

8 Muliyawan. 2015. Paradigma Baru Hukum Perlindungan Anak Pasca Perubahan Undang-Undang Perlindungan Anak, Available from http://www.pn-palopo.go.id/index.php/berita/artikel/ paradigma-baru-hukum-perlindungan-anak - pasca - perubahan - undang - undangperlindu ngan anak, accessed on 1 June 2020
} 
crimes against children such as violence, sexual abuse, slavery, and trafficking which will ultimately threaten the children's welfare.

Child protection must be integral/simultaneous both juridically/penal or nonjuridically/ non-penal. What is meant by the penal policy is an effort made by improving the existing laws if they do not meet legal certainty; therefore, the hope is that legal certainty will create a sense of justice in the law itself. It can also be said that the penal policy focuses more on the nature of "repressive" (oppression/eradication/suppression) effort after the crime occurred, for example, protection under criminal law, ${ }^{9}$ civil law, and customary law (where it can be included in awig-awig). Whereas non-penal policy focuses more on the nature of "preventive" (prevention/deterrence/control) effort before a crime occurs; therefore, it can be said that this non-penal policy is the most strategic effort. Examples of the non-penal policy are social protection, education, family, health, and the environment. ${ }^{10}$

In terms of the penal policy, the State has provided a legal umbrella through the Law of the Republic of Indonesia No. 35 of 2014 on the Amendment of the Law of the Republic of Indonesia No. 23 of 2002 on Child Protection (Law No. 35/2014). It aims to guarantee a child's life to run normally. However, as time goes by such Law is deemed unable to run effectively because there is still overlap between sectoral regulations related to the definition of child and on the other side the crime against children is increased. ${ }^{11}$

Based on the Data collected from the KPAI between 2011 to 2015, it is noted that there were 2.178 cases (2011), 3.512 cases (2012), 4.311 cases (2013), 5.066 cases (2014) and 6.006 cases (2015). ${ }^{12}$ Therefore, considering the said paradigm, the Law of the Republic of Indonesia No. 23 of 2002 on Child Protection (Law No. 23/2002) was finally amended by No. 35/2014. Law No. 35/2014 emphasizes the need for the imposition of criminal sanctions and fines for perpetrators in order to create a deterrent effect and encourage concrete steps to recover the physical, psychological and social well-being of children.

Law No. 35/2014 which came into effect on 18 October 2014 has undergone many changes, including giving responsibilities and obligations to the state, government, regional government, society, family and parents or guardians in terms of implementing child protection, and raising the provisions on minimal penalties for perpetrators of sexual crimes against children, as well as introducing a new legal system namely repressive victim protection in the form of compensation, in this case, the right of restitution.

Some of the previous research articles have reviewed non-penal policies; however, their studies have not yet led to the Jagaddhita family. Such findings were only related to non-penal policy in overcoming radical understanding by instilling religious and

\footnotetext{
${ }^{9}$ Arief, N. B. 1991. Upaya Non Penal dalam Kebijakan Penanggulangan Kejahatan, Seminar Material in Criminology VI in Semarang.

${ }_{10}^{10} \mathrm{Ibid}$.

11 Muliyawan, 2015, Loc. Cit.

${ }^{12}$ Merta, S. P. Putu. 2015, Komnas PA: Kekerasan Anak Tertinggi Selama 5 Tahun Terakhir. Available from http://news.liputan6.com/read/2396014/ komnas - pa - 2015 - kekerasan-anaktertinggi-selama-5-tahun-terakhir, accessed on 1 June 2020
} 
moral education since the early stage, ${ }^{13}$ providing internet access restriction penalties by detecting traces of crime in cyberspace, ${ }^{14}$ diversion and restorative justice related to child crimes. ${ }^{15}$

Based on the above background, to round off violence and exploitation against children, the problem raised in this article is "How does the Jagaddhita family save children from violence and exploitation?".

\section{Research Methodology}

This article uses the normative juridical research method, a normative approach based on literature studies. It employs statutory, sociological, and conceptual approaches. The collected legal materials are analyzed qualitatively using relevant theories.

\section{Results and Discussions}

\subsection{Indonesian Children are in The State of Emergency}

Violence against children is increasing every year. Children as victims of violence continue to increase even though the state has continued to try to provide child protection by providing several laws and regulations related to it. For example, there are Law No. 35/2014 and Presidential Instruction of the Republic of Indonesia Number 5 of 2014 on the National Movement Against Sexual Crimes to Children (Presidential Instruction No.5/2014). As already stated above, based on the Data collected from the KPAI between 2011 to 2015, it is noted that there were 2.178 cases (2011), 3.512 cases (2012), 4.311 cases (2013), 5.066 cases (2014) and 6.006 cases (2015). ${ }^{16}$

Violence in the educational sector has even taken its toll on educators and education staff. Two of the viral cases in Gresik and Takalar, are small representations of an assault case against the educators and education staff. There are still many other cases that may not or have not been revealed in the media. Although the number is still relatively small compared to cases involving children as victims, such cases must be of particular concern to the Indonesian educational world, in this case, the Ministry of Education as the policymaker. It cannot be denied that the occurrence of such cases is an indication of the threat of moral degradation, which requires character building strengthening. ${ }^{17}$

Taken into account cases on children's violation and exploitation that continues to increase every year; therefore, it can be said that we no longer only rely on the penal policy alone. It is because there are three (3) stages in dealing with violence cases,

13 Winarni, L. N. (2016). Kebijakan Hukum Pidana Non Penal Dalam Penanggulangan Kejahatan Radikalisme Berbentuk Terorisme. DiH: Jurnal Ilmu Hukum, 12(23), p. 56-63.

${ }^{14}$ Djanggih, H. (2018). Konsepsi Perlindungan Hukum Bagi Anak Sebagai Korban Kejahatan Siber Melalui Pendekatan Penal Dan Non Penal. Mimbar Hukum-Fakultas Hukum Universitas Gadjah Mada, 30(2), p. 316-330.

15 Fithri, B. S. (2018). Pendekatan Integral Penal Policy Dan Non Penal Policy Dalam Penanggulangan Kejahatan Anak. Doktrina: Journal of Law, 1(2), p. 69-89.

16 Merta, S. P. Putu. 2015, Loc.Cit.

${ }^{17}$ Atmojo, Suryo. 2019. Peran Penguatan Pendidikan Karakter Dalam Menanggulangi Kekerasan Pada Lembaga Pendidikan. Buletin Jagaddhita, 1(2), p. 1 
namely: (1) Prevention, (2) Handling, (3) Rehabilitation. ${ }^{18}$ It often happens that we only focus on the handling stage and forget that the upstream is the prevention stage. This prevention effort should be of concern to all of us, as a non-penal policy. The non-penal policy is an effort to end violence against children ${ }^{19}$. This non-penal policy is in line with the flagship program of the Ministry of Women's Empowerment and Child Protection issued in 2016 called "Three Ends". Three Ends consisted of (1) end violence against women and children; (2) end human trafficking; (3) end economic inequality. The word "end" means "no more". Therefore, the prevention stage is the stage that must be implemented. 20

The active role of society, individuals, and the government is very important in handling sexual violence against children by considering the impacts experienced by the victims.

A system-based approach is needed in dealing with such cases. An effective child protection system requires interrelated components. These components include a social welfare system for children and families, a justice system that complies with international standards, and a mechanism to encourage appropriate behavior in society. In addition, adequate legal and policy frameworks as well as data and information systems for child protection are also needed..$^{21}$

\subsection{The Jagaddhita Family As Non-Penal Policy}

In Hinduism, there are various ceremonies performed since a child is in his/her mother's womb. Each ceremony is performed according to the development of a child's age. Those are intended as ways to build the character and personality of a child. One of the ceremonies is the "tujuh bulanan" ceremony which is held when the fetus is seven months old in his/her mother's womb. That constitutes as a purification ceremony. Therefore, they pray to Ida Sang Hyang Widhi Wasa so that the fetus becomes a perfect baby, survived in its life, and grows into a good (suputra) child.

Hindu scripture requires a pregnant woman to maintain her manners because it will, later on, affect the baby's character. The holy book of Padma Purana states that it is not allowed for a mother to do things that are not good. She must always maintain the purity of herself, her words - so it makes happiness for those who hear it, her good manners, her respect for in-laws, and her wishes to make her husband happy. ${ }^{22}$ In essence, a mother should guard her thoughts, words, and behavior based on dharma because the baby who is still in the womb has the ability to record vibrations from the outside. ${ }^{23}$

18 Tini, R. AAA N. 2013. Menuju Bali Ramah Keluarga ( Melalui Keluarga Menyelamatkan Bali). Bekasi: Ganeca Exact, p. 2

19 Tini, R. AAA N. 2013. Ibid.

${ }^{20}$ Ngesti, S. M. 2016. Strategi Three Ends Menggalang Wanita Kuat Indonesia untuk Akhiri Kekerasan. 2016, available from http://www.kompasiana.com/kinantisekardjagad/strategi-three-endsmenggalang-wanita-kuat-indonesia-untuk-akhiri-kekerasan, accessed on 30 May 2020

${ }^{21}$ Noviana, I. (2015). Kekerasan seksual terhadap anak: dampak dan penanganannya. Sosio Informa, 1(1). p. 13-28

22 Budiadnya, P. (2019). Op.cit. p. 131

${ }^{23}$ Budiadnya, P. (2019). Ibid. 
The obligation of looking after a child's development to achieve his/her satisfaction of psychological needs lies not only with the mother but also on the emotional maturity of the parents. Parental emotional maturity will cause children to develop healthy toward positive self-maturity. If negative emotions fill the child's family, the child will feel uncomfortable and inhibit the child's expression. ${ }^{24}$

The non-penal policy is the most strategic effort in eliminating any crime against children. This article focuses on the existence of the Jagaddhita family as a form of nonpenal policy. A man (purusa) and a woman (pradhana) promise to live in a spiritual bond based on loyalty and love. A marriage has four (4) main objectives namely Dharma, Artha, Kama, and Praja that will lead to the birth of good children. Therefore, a child born in the right process through the strengthening of the Jagaddhita family is the goal of such marriage. ${ }^{25}$

A marriage to the Jagaddhita family. First, Dharma is a truth that is believed by both partners to always live in an atmosphere of full certainty and harmony. It is because Dharma is essentially the certainty and order in human life. Whatever happens in life must be based on truth. Of course, these values are based on the spirit to live together in harmony by considering the values of local wisdom and the Indonesian philosophy of Pancasila. ${ }^{26}$ Truth comes from choosing a life partner that we believed will bring happiness and peace to our life.

Second is Artha which means economic welfare in marriage. This is a natural goal that every human being would want this. A husband must have a steady income to be able to support his family in order to pursue happiness from the side of Artha. However, due to the growing demands of life, women are now expected to be able to contribute to increasing family income for family welfare. Fulfillment of material needs must also be based on Dharma (truth) so that the fulfillment of economic prosperity does not cause new problems which later may lead to improper use of Artha and cause law violation.

Third, Kama is also no less important than those two points mentioned above. Kama is psychological happiness, which in this case the marriage must be able to provide love, mutual love, a sense of belonging, give rise to a sense of security, comfort, and happiness. In order to pursue happiness in the family, such feelings should be coupled with Dharma as well.

The last purpose of marriage is Praja. It means marriage is conducted to give birth to descendants and to maintain them becoming good children (suputra) who will later become the successors of the family, nation, and state. ${ }^{27}$ As the successors to the nation and due to children's physical and mental that are still immature, children need special protection that is different from adults.

24 Solihin, L. (2004). Tindakan kekerasan pada anak dalam keluarga. Jurnal Pendidikan Penabur, 3(3), 133. p. 129-139

${ }^{25}$ Gorda, I G. N. (1997). Dasar Moral Dan Motivasi Membina Perkawinan Bahagia Menurut Pandangan Hindu. Denpasar: Sekolah Tinggi Ilmu Ekonomi Satya Dharma bekerja sama dengan Widya Kriya Gematama Denpasar, p. 12

${ }^{26}$ Dharmawan, NKS., et'al. (2019). Personal data protection and liability of internet service provider: a comparative approach. International Journal of Electrical and Computer Engineering (IJECE, 9(4), pp. 3175 3184

${ }^{27}$ Gorda, I G. N. (1997). Op.Cit. p. 15 
Special protection for children related to protection from violence and discrimination in accordance with human dignity and children's constitutional rights to ensure the fulfillment of children's rights; therefore, they can grow, develop and participate optimally, can be seen in Article 28 B paragraph (2) of the 1945 Constitution of the Republic of Indonesia (1945 Indonesian Constitution). The article stipulates that every child shall have the right to live, to grow and to develop, and shall have the right to protection from violence and discrimination. Therefore, based on this norm, the state is seen as obliged and responsible for child protection. Such protection must be oriented to the protection of children's principles. That is because Indonesia has ratified the Convention on the Rights of the Child (CRC), which includes:

1. Non-Discrimination means all have the same rights and treatment without discrimination over race, color, sex, language, and religion.

2. The best interests of children. This means that this principle is put as the main consideration in all actions for children carried out by the State/Government.

3. The right to life, survival, and development of children means the most basic human rights for children that must be protected by the State/Government.

4. Respect for the child's opinion means respect for the rights of children to participate and express their opinions in decision making.

There are many theories on child development. One of them is the Attachment Theory which links knowledge about parenting and child care. A process of someone's growth from a child to a teenager is very important. That is the perfect time for them to be introduced to their environment, life values, morals, norms, and social rules as their guidance in living their lives. ${ }^{28}$

A child who experienced violence in his/her past will tend to have the potential to commit violence when he/she is an adult. Children who experience violence (whether as victims or perpetrators) need special attention from all parties, especially families (parents), the government, and other stakeholders. This requires a strategy of combating acts of violence from various parties in order to be able to run holistically and comprehensively. ${ }^{29}$

The family is the first and foremost place to implement special child protection. We all should live our life properly and follow good paths; therefore, we have a good family, a good place for our children to born. In Hinduism, there are four (4) processes of life called Catur Asrama. Those processes are as follow:

The process referred to in Hindu views is called Chess Boarding consisting of:

1. Brahmacari. It is the first stage that must be passed by humans born in this world. In this stage, humans try to do self-learning and to distinguish the quality of ourselves. Therefore, education is the key to the process.

2. Grihasta. It is the second stage that must be followed by humans after educating themselves with knowledge (Brahmacari). The second goal is to develop a prosperous and happy family.

\footnotetext{
${ }^{28}$ Tini, Rusmini, AAA Ngurah. (2013). Kebijakan Formulasi Terhadap Perlidungan Anak Sebagai Korban Pedofilia, Dissertation Summary, Malang, Universitas Brawijaya.

${ }^{29}$ Hasanah, U., \& Raharjo, S. T. (2016). Penanganan kekerasan anak berbasis masyarakat. Share: Social Work Journal, 6(1). 80-92
} 
3. Vanaprastha. It is the third stage of life in terms of spiritual and moral enhancement. Human starts to get close to spiritual and religious problems in life.

4. Sanyasin is the most important and final level of process that can be realized. It is the stage where we serve our life only to God. ${ }^{30}$

These processes should be done properly in order to give birth to good (suputra) children. The first stage, Brahmacari, closely related to the concept of good (suputra) children. With the correct knowledge, humans will be able to understand the essence of life. Therefore, humans are expected to face the second stage, Grihasta, a stage of life where humans perform a marriage, with a correct understanding of their life choices; therefore, they can build a happy and prosperous family. Hence, Brahmacari plays an important role before humans face the Grihasta stage.

A suputra or good child from the Hindu perspective means:

1. A child who can later carry the good reputation of his/her family name;

2. A child who opens the way for their parents to heaven;

3. A child who continues life as the second generation for his/her families. ${ }^{31}$

Thus, a suputra child has a very strategic position for the future of his/her family, nation, and country. Children are the nation's assets that must be protected especially during their growth and development stages. All the best and necessary supports must be given to the children in order to create suputra children that are also free from violence and exploitation.

\subsection{Jagaddhita Family Saves Children from Violence and Exploitation}

It has been explained before, the parenting style of the Jagaddhita family is in line with what has been prepared by the United Nations International Children's Fund (UNICEF), namely the strategy of handling and preventing violence against children by supporting parents, caregivers, and families. So, the parenting style of the Jagaddhita Family and UNICEF indicates an approach that prevents violence from happening and minimizes the factors that trigger violence and vulnerability in the family. ${ }^{32}$

According to Article 1 of the Law of the Republic of Indonesia No. 1 of 1974 on Marriage (Law No. 1/1974) marriage is a relationship of body and soul between a man and a woman as husband and wife with the purpose of establishing a happy and lasting family (household) founded on the belief in God Almighty. The definition of marriage referred to in Article 1 of Law No. 1/1974 has the same meaning as the marriage definition according to the Hindu view as revealed in the Holy Book of Manawa Dharmsastra, IX.102. It basically states that a man and a woman who bound in marital ties must keep trying to maintain their marriage, so, no divorce and they must not violate loyalty between one another. ${ }^{33}$

\footnotetext{
30 Gorda, I G. N. (1997). Op.Cit. p. 18

31 Gorda, I G. N. (2006). Op.Cit., p. 16

32 Hasanah, U., \& Raharjo, S. T. (2016). Penanganan kekerasan anak berbasis masyarakat. Share:

Social Work Journal, 6(1). 80-92

33 Gorda, I G. N. (2006). Loc.Cit..
} 
There are three (3) main points can be drawn from the same meaning of the two definitions of marriage mentioned above: (1) a relationship of body and soul between a man and a woman as husband and wife; (2) the purpose of marriage is to be happy; and (3) marriage cannot be separated except if it is the God's will. If a man and a woman have agreed to build a household then the main guidelines are the provisions as stated in the sloka/holy book or Article 1 of the Law No. 1/1974; therefore, such a household will have a strong and good foundation to later on raising their children. As already mentioned previously, the purpose of the marriage itself is towards a Jagaddhita family or a happy family based on the Dharma, Artha, Kama, and Praja. ${ }^{34}$

Dharma is the foundation of truth. Therefore every action of a husband and wife must be based on Dharma in order to achieve certainty and to create Jagaddhita family. The implementations of Dharma in the Jagaddhita family can be seen from a husband and wife's behaviors where they intelligently understand and practice the values related to truth, virtue, and loyalty based on the holy book. In the end, those implementations will lead them to a strong soul that has a high sense of devotion to God (Ida Sang Hyang Widhi Wasa). This soul must be strong enough to create the Jagaddhita family.

Artha or wealth is a major requirement in the continuity of the Jagaddhita family. Artha can be said to be welfare. A husband and wife must be smart in managing their Artha based on the Dharma. Kama is also another need that must be sought to exist. It is because, in addition to material needs (Artha), human also has non-material needs (Kama). Kama emphasizes the psychological impact such as the need for security, calmness, comfort, pleasure, and happiness. Praja is also the most strategic goal in building a family, which is to give birth to children as descendants. This purpose will determine whether the family will give birth to good (suputra) children or not. Therefore, it is important to pursue the creation of a Jagaddhita family in order to create suputra children that are also free from violence and exploitation.

The Jagaddhita family which is based on Hindu's values like Tri Hita Karana values (harmonious relationship between human and God, human and human, as well as human and environment) and the Karmaphala (a law of cause and effect believed by Hindus) can become a non-penal policy in saving children from child abuse and exploitation. ${ }^{35}$

Crimes against children continue to lurk our children; therefore, it takes the government's commitments both in terms of regulation, law enforcement. This includes mass media which is needed to play a role in building a good culture and extensive knowledge through its information. Simultaneous and thorough cooperation from parents, society, and the government is needed to ensure the children's safety from sexual crimes that may occur. ${ }^{36}$ Hence, all parties need to establish relationships

${ }^{34}$ Gorda, I G. N. (1997). Op.Cit. p. 28.

${ }^{35}$ Karyati, N. K., \& Suryathi, N. W. (2019, December). Kekuatan Tri Hita Karana Dalam Menjaga Kelangsungan Pertanian (Studi Pada Gapoktan Mekar Sari Badung). In Seminar Nasional Inovasi dalam Penelitian Sains, Teknologi dan Humaniora-InoBali (pp. 1040-1048).

36 Probosiwi, R., \& Bahransyaf, D. (2015). Pedofilia dan kekerasan seksual: masalah dan perlindungan terhadap anak. Sosio Informa, 1(1). p. 29-40 
based on values in the Jagaddhita Family as a non-penal policy in suppressing acts of violence against children. ${ }^{37}$

\section{Conclusion}

The handling of child abuse cases requires integral or simultaneous efforts that prioritize effective prevention processes (Non-penal policy). The most effective prevention is to form and realize a Jagaddhita (happy) family. The Jagaddhita family establishment, as a form of non-penal policy, is very strategic in eliminating any crime related to children. Forming a Jagaddhita Family is the goal of a marriage that has four (4) main objectives, namely Dharma, Artha, Kama, and Praja, that will give birth to good children. Simultaneous and thorough cooperation from parents, society, and the government is needed to ensure the children's safety from crimes against children that may occur.

\section{References}

\section{Books}

Gorda, I G. N. (1997). Dasar Moral Dan Motivasi Membina Perkawinan Bahagia Menurut Pandangan Hindu. Denpasar: Sekolah Tinggi Ilmu Ekonomi Satya Dharma in collaboration with Widya Kriya Gematama Denpasar.

Gorda, I G. N. (2006). Mendidik Suputra Dalam Kandungan Ibu, Denpasar: Astra Brata Bali.

Nashriana. (2011). Perlindungan Hukum Pidana Bagi Anak di Indonesia. Jakarta: PT Raja Grafindo Persada.

Tini, R. AAA N. (2013). Menuju Bali Ramah Keluarga ( Melalui Keluarga Menyelamatkan Bali). Bekasi: Ganeca Exact.

\section{Journal \& Proceeding}

Atmojo, S. (2019). Peran Penguatan Pendidikan Karakter Dalam Menanggulangi Kekerasan Pada Lembaga Pendidikan. Buletin Jagaddhita, 1(2), 1-5.

Budiadnya, P. (2019). Peran Guru Rupaka Daalam Menanamkan Ajaran Agama Hindu Dalam Keluarga Di Kota Surakarta. Kamaya: Jurnal Ilmu Agama, 2(2), 123-142.

Dharmawan, NKS., et.al. (2019). Protecting Balinese Culinary Innovation through Patent Law. International Journal of Innovation, Creativity and Change, 9(10), pp. 116-126

Djanggih, H. (2018). Konsepsi Perlindungan Hukum Bagi Anak Sebagai Korban Kejahatan Siber Melalui Pendekatan Penal Dan Non Penal. Mimbar HukumFakultas Hukum Universitas Gadjah Mada, 30(2), 316-330. https://doi.org/10.22146/jmh.32017

Fithri, B. S. (2018). Pendekatan Integral Penal Policy Dan Non Penal Policy Dalam Penanggulangan Kejahatan Anak. Doktrina: Journal of Law, 1(2), 69-89 https://doi.org/10.31289/doktrina.v1i2.1922

Hanifah, H., \& Raharjo, S. T. (2018). Relasi Orangtua, Anak Dan Peer Group (Penemuan Konsep Diri Pada Remaja, Kasus Pada Siswa Sman Tanjungsari

\footnotetext{
${ }^{37}$ Hanifah, H., \& Raharjo, S. T. (2018). Relasi Orangtua, Anak Dan Peer Group (Penemuan Konsep Diri Pada Remaja, Kasus Pada Siswa Sman Tanjungsari Sumedang). Focus: Jurnal Pekerjaan Sosial, 1(2), 124-134.
} 
Sumedang). Focus: Jurnal Pekerjaan Sosial, 1(2), 124-134. https://doi.org/10.24198/focus.v1i2.18277

Hasanah, U., \& Raharjo, S. T. (2016). Penanganan kekerasan anak berbasis masyarakat. Share: Social Work Journal, 6(1). https://doi.org/10.24198/share.v6i1.13150

Karyati, N. K., \& Suryathi, N. W. (2019, December). Kekuatan Tri Hita Karana Dalam Menjaga Kelangsungan Pertanian (Studi Pada Gapoktan Mekar Sari Badung). In Seminar Nasional Inovasi dalam Penelitian Sains, Teknologi dan Humaniora-InoBali, pp. 1040-1048.

Nurwita, A., Nurfitriani, E., \& Yuniarti, S. (2017). Hubungan Status Ekonomi Dan Pandangan Posisi Anak Dengan Sikap Orang Tua Terhadap Kekerasan Pada Anak. Jurnal Kesehatan, 8(1), 955-960. https://doi.org/10.38165/jk.v8i1.103

Probosiwi, R., \& Bahransyaf, D. (2015). Pedofilia dan kekerasan seksual: masalah dan perlindungan terhadap anak. Sosio Informa, 1(1). 29-40

Sofian, A., Pratama, B., \& Talerico, C. (2018). Weighting Approaches on Online Sexual Abuse of Children: Cultural Prevention or Crime-Based Enforcement?. Udayana Journal Of Law And Culture, 2(2), 191-219. https://doi.org/10.24843/UJLC.2018.v02.i02.p04

Supasti Dharmawan, N. K., Dewi Kasih, D. P., \& Stiawan, D. (2019). Personal data protection and liability of internet service provider: a comparative approach. International Journal of Electrical \& Computer Engineering, 9(4), pp. 3175 3184, https:// doi.org/10.11591/ijece.v9i4.pp3175-3184

Winarni, L. N. (2016). Kebijakan Hukum Pidana Non Penal Dalam Penanggulangan Kejahatan Radikalisme Berbentuk Terorisme. DiH: Jurnal Ilmu Hukum, 12(23), 5663.

\section{Thesis or Dissertation}

Tini, Rusmini, AAA Ngurah. (2013). Kebijakan Formulasi Terhadap Perlidungan Anak Sebagai Korban Pedofilia, Dissertation Summary, Malang, Universitas Brawijaya.

\section{Colloquium}

Arief, N. B. (1991). Upaya Non Penal dalam Kebijakan Penanggulangan Kejahatan, Seminar Material in Criminology VI in Semarang.

\section{Online/World Wide Web}

Merta, S. P. Putu. (2015). Komnas PA: Kekerasan Anak Tertinggi Selama 5 Tahun Terakhir. Retrieved from http://news.liputan6.com/read/2396014/ komnas - pa - 2015 - kekerasan-anak-tertinggi-selama-5-tahun-terakhir, accessed on 1 June 2020

Muliyawan. (2015). Paradigma Baru Hukum Perlindungan Anak Pasca Perubahan Undang-Undang Perlindungan Anak. Retrieved from http://www.pnpalopo.go.id/index.php/berita/artikel/_ paradigma-baru-hukumperlindungan-anak - pasca - perubahan - undang - undang- perlindu ngan anak, accessed on 1 June 2020.

Ngesti, S. M. (2016). Strategi Three Ends Menggalang Wanita Kuat Indonesia untuk Akhiri Kekerasan. Retrieved from http://www.kompasiana.com/kinantisekardjagad/strategi-three-endsmenggalang-wanita-kuat-indonesia-untuk-akhiri-kekerasan, accessed on 30 May 2020 
Dwi, Y. (2010). Perlindungan Hak Asasi Manusia Anak di Indonesia: Perkembangan, Implementasi, dan Rekomendasi. Retrieved from https://nunutngombe.wordpress.com/2010/10/28/ perlindungan-hak-asasimanusia-anak-di-indonesia-perkembangan-implementasi-dan-rekomendasi, accessed on 1 June 2020

Fitroh, M. (2014). Perlindungan Hak Asasi Manusia Anak di Indonesia. Retrieved from http:// www.kompasiana.com/fitrohmufidatul/perlindungan-hak-asasimanusia-anak-di-indonesia, accessed on 1 June 2020

\section{Laws and Regulations}

The 1945 Constitution of the Republic of Indonesia

The Law of the Republic Indonesia No. 39 of 1999 on Human Rights, State Gazette of the Republic Indonesia of 1999 Number 165, Supplementary to the State Gazette of the Republic Indonesia Number 3886

The Law of the Republic of Indonesia No. 20 of 2003 on National Educational System, State Gazette of the Republic Indonesia of 2003 Number 78, Supplementary to the State Gazette of the Republic Indonesia Number 430

The Law of the Republic of Indonesia No. 35 of 2014 on the Amendment of The Law of the Republic of Indonesia No. 23 of 2002 on Child Protection, State Gazette of the Republic Indonesia of 2002 Number 109, Supplementary to the State Gazette of the Republic Indonesia Number 4235

the Law of the Republic of Indonesia No. 1 of 1974 on Marriage, State Gazette of the Republic Indonesia of 1974 Number 1, Supplementary to the State Gazette of the Republic Indonesia Number 3019

Presidential Instruction of the Republic of Indonesia Number 5 of 2014 on the National Movement Against Sexual Crimes to Children

Convention on the Rights of the Child 